
\title{
COMPARISON OF PERIODONTITIS DIAGNOSES ACCORDING TO 1999
AND 2017 CLASSIFICATIONS: AN ORIGINAL ARTICLE
}

\begin{abstract}
Objectives: Classification systems of periodontitis have changed several times over the past 30 years as new information gathered about the pathophysiology of the disease rendered previous systems inadequate for classifying the diagnoses of all patients. Although the 1999 classification system was widely used in clinical practice and scientific studies, it had significant limitations leading to the reclassification introduced in 2017. In this context, the aim of this study is to evaluate how individuals diagnosed with periodontitis under the 1999 system were reclassified according to the 2017 system.
\end{abstract}

Materials and Methods: Participants diagnosed with periodontitis according to 1999 classification and who had not received periodontal treatment in the last six months were included in the study. The patient assessment procedure consisted of a comprehensive periodontal diagnosis through periodontal charting and full-mouth radiography.

Results: A total of 315 subjects (133 males and 182 females) were included in the study. According to the new classifications, 42 patients (17.94\%) previously diagnosed with generalized chronic periodontitis according to 1999 classifications, were now classified as healthy with reduced periodontium, and $11(4.7 \%)$ patients were classified as gingival inflammation with reduced periodontium. 63 (26.92\%) patients were classified as SIII-GC and 33 patients (14.14\%) as SIV-GC.

Conclusions: The new classification system is based on not only disease severity but also the dimensions of an individual's disease which include complexity and risk factors.

\author{
DFatih KARAASLAN ${ }^{1}$ \\ (D) Ahu DİKILITAS ${ }^{1}$ \\ (D) Esra Özge AYDIN ${ }^{1}$
}

ORCID IDs of the authors: F.K. 0000-0002-9899-3316 A.D. $0000-0003-4130-2526$ E.Ö.A. 0000-0001-8166-560X

\footnotetext{
${ }^{1}$ Department of Periodontology, Faculty of Dentistry, Usak University Usak Turkey
}

$\begin{array}{ll}\text { Received } & : 07.10 .2019 \\ \text { Accepted } & : 26.11 .2019\end{array}$

Keywords: Classification, diagnosis, disease, periodontitis.

How to Cite: Karaaslan F, Dikilitaș A, Aydın EÖ. Comparison of Periodontitis Diagnoses According to 1999 and 2017 Classifications: An Original Article. Cumhuriyet Dent J 2019;22:4;

*Corresponding Author:

Department of Periodontology, Faculty of Dentistry, Usak University, Usak Turkey.

Phone: +90 5538721783 Email: fatih.karaaslan@usak.edu.tr 


\section{INTRODUCTION}

Periodontitis is a microbially associated and host mediated multifactorial inflammatory disease characterized by loss of periodontal attachment. ${ }^{1}$ Periodontitis classification has been modified several times in the last 30 years in accordance with emerging scientific findings. ${ }^{2}$ The periodontitis classification system widely accepted in 1999 was used in both clinical practice and scientific research, despite its important deficiencies, such as the lack of pathobiology-based distinctions, diagnostic imprecision, and difficulties in practice. ${ }^{3}$ The analysis of these important shortcomings prompted the reclassification of periodontitis in the 2017 workshop. $^{4}$

The result of the 2017 workshop provides a current and future-oriented classification of the periodontal status of patients. Three types of periodontitis have been defined in the new classification: a) periodontitis, b) necrotizing periodontitis, and c) periodontitis as a manifestation of systemic disease. A staging and grading system was created to replace the term "aggressive periodontitis." Periodontitis was reclassified into four stages (I, II, III, and IV) according to severity of the disease, and three grades (A, B, and $\mathrm{C}$ ) to differentiate disease susceptibility. ${ }^{5}$ Importantly, the terms "clinical health" and "intact and reduced periodontium" were defined. ${ }^{6}$

The 2017 classification system addresses unresolved problems in the earlier system and provides a "future-proof" system for classifying periodontitis. This study evaluates how individuals diagnosed with periodontitis under the 1999 system are to be reclassified using the 2017 parameters.

\section{MATERIALS AND METHODS}

This study was conducted from February 2019 to August 2019 at the Faculty of Dentistry of Usak University. Participants were informed about the purpose of the investigation and informed consent forms were signed. The study was conducted according to the Helsinki Declaration's norms, and ethical approval was granted by the Local
Ethical Committee of Usak University (Registration No: 226-04).

A comprehensive periodontal diagnosis was undertaken in the patient assessment procedure through periodontal charting and full-mouth radiography. Participants who had been diagnosed with periodontitis according to 1999 classifications and who had not received periodontal treatment in the previous six months were included in the study. The patients diagnosed under 1999 parameters as having chronic or aggressive periodontitis were reviewed by a calibrated periodontologist (AD). Patients' periodontitis was reported as localized if $\leq 30 \%$ of the sites were affected-otherwise, as generalized. ${ }^{7,8}$

The same patients were re-evaluated according to the 2017 classification system by another calibrated investigator (FK) who was blind to their 1999 classifications. The patients were diagnosed as having periodontitis under these criteria: their interdental clinical attachment loss (CAL) was detectable at $\geq 2$ non-adjacent teeth; their buccal or oral CAL was $\geq 3 \mathrm{~mm}$ with pocketing $>3 \mathrm{~mm}$ detectable at $\geq 2$ teeth $;{ }^{5}$ and the observed CAL could not be attributed to nonperiodontitis causes. Periodontitis patients who do not have a probing pocket depth (PPD) of $4 \mathrm{~mm}$ or more, and with bleeding on probing (BoP) lower than $10 \%$, were diagnosed with reduced periodontium; those with $\mathrm{BoP}$ higher than $10 \%$ were diagnosed as having reduced periodontium with gingival inflammation. If periodontitis patients had a PPD of $4 \mathrm{~mm}$ or more, periodontitis needs to be assessed as to stage and grade..$^{9,10}$

The stages are based primarily on the worstaffected tooth's interdental CAL. The complexity score depends on the difficulty of treating the case, considering factors like deep probing depths, furcation involvement, and vertical defects. Subclassification of stages was reported as localized if $<30 \%$ of teeth were affectedotherwise, as generalized. ${ }^{5,10}$

Grade is based on the assessment of bone loss at the worst-affected tooth as a function of age. It is measured as radiographic bone loss in a 
percentage of root length divided by the patient's age. Grades A and B can be modified if the patient smokes or is diabetic. ${ }^{5,10}$

Data analysis was performed by using the software Statistical Package version 17.0 (SPSS Inc., Chicago, IL, USA). Descriptive statistics were used to evaluate the data in this study.

\section{RESULTS}

A total of 315 patients (133 males and 182 females) were included in the study. According to 1999 classifications, 234 (74.28\%) of these patients suffered from generalized chronic periodontitis, $38(12.06 \%)$ from generalized aggressive periodontitis, 21 (6.68\%) from localized chronic periodontitis, and 22 (6.98\%) from localized aggressive periodontitis.

Under the new classification system, 42 patients (17.94\%) diagnosed with generalized chronic periodontitis in the 1999 system were reclassified as healthy and reduced periodontium, and $11(4.7 \%)$ were reclassified as gingival inflammation with reduced periodontium. Sixtythree patients (26.92\%) were classified as SIII-GC (stage III, grade C) and $33(14.14 \%$ ) as SIV-GC (Table 1).

Table 1. The new classification of patients with chronic periodontitis

\begin{tabular}{|c|c|c|c|c|c|c|c|c|c|c|c|}
\hline \multirow{2}{*}{$\begin{array}{c}1999 \mathbf{C} \\
\mathrm{n} / \%\end{array}$} & \multicolumn{10}{|c|}{$2017 \mathrm{C} \mathrm{n} / \%$} & \multirow{2}{*}{$\begin{array}{l}\text { Total } \\
\mathrm{n} / \%\end{array}$} \\
\hline & $\mathbf{R P}$ & RPG & N-RPG & $\begin{array}{l}\text { SII - } \\
\text { GB }\end{array}$ & $\begin{array}{l}\text { SII- } \\
\text { GC }\end{array}$ & $\begin{array}{l}\text { SIII- } \\
\text { GA }\end{array}$ & $\begin{array}{l}\text { SIII- } \\
\text { GB }\end{array}$ & $\begin{array}{l}\text { SIII- } \\
\text { GC }\end{array}$ & $\begin{array}{l}\text { SIV- } \\
\text { GB }\end{array}$ & $\begin{array}{l}\text { SIV- } \\
\text { GC }\end{array}$ & \\
\hline GCP & $\begin{array}{l}42 / \\
17.94\end{array}$ & $\begin{array}{l}11 / \\
4.7\end{array}$ & - & $\begin{array}{l}19 / \\
8.11\end{array}$ & $\begin{array}{l}22 / \\
9.4\end{array}$ & $6 / 2.56$ & $\begin{array}{l}31 / \\
13.24\end{array}$ & $\begin{array}{l}63 / \\
26.92\end{array}$ & $7 / 2.99$ & $\begin{array}{l}33 / \\
14.14\end{array}$ & $\begin{array}{l}234 / \\
100\end{array}$ \\
\hline LCP & $\begin{array}{l}5 / \\
23.80\end{array}$ & - & $2 / 9.53$ & - & - & - & $\begin{array}{l}8 / \\
38.09\end{array}$ & $\begin{array}{l}6 / \\
28.58\end{array}$ & - & - & $\begin{array}{l}21 / \\
100\end{array}$ \\
\hline Total & $\begin{array}{l}47 / \\
18.43\end{array}$ & $\begin{array}{l}11 / \\
4.31\end{array}$ & $\begin{array}{l}2 / \\
0.78\end{array}$ & $\begin{array}{l}19 / \\
7.45\end{array}$ & $\begin{array}{l}22 / \\
8.62\end{array}$ & $6 / 2.35$ & $\begin{array}{l}39 / \\
15.29\end{array}$ & $\begin{array}{c}69 / \\
27.05\end{array}$ & $7 / 2.74$ & $\begin{array}{l}33 / \\
12.98\end{array}$ & $\begin{array}{l}255 / \\
100\end{array}$ \\
\hline
\end{tabular}

C: Classification

RP: Reduced periodontium

RPG: Reduced periodontium with gingival inflammation

N-RPG: Non periodontitis caused reduced periodontium with gingival inflammation

LCP: Localized chronic periodontitis

GCP: Generalized chronic Periodontitis

Five $(23.80 \%)$ patients who were diagnosed with localized chronic periodontitis using 1999 parameters were reclassified as healthy and reduced periodontium. Two patients $(9.53 \%)$ were classified as reduced periodontium and gingival inflammation from non-periodontitis causes (Table 1).
Of the patients diagnosed with generalized aggressive periodontitis according to 1999 classification, 21 (55.27\%) were classified as SIVGC, and 13 patients (59.09\%) diagnosed with localized aggressive periodontitis according to 1999 classifications were classified as SIII-GC (Table 2).

Table 2. The new classification of patients with agressive periodontitis

\begin{tabular}{cccc}
\hline $\begin{array}{c}\text { 1999 C } \\
\text { n } \%\end{array}$ & SIII-GC & SIV-GC & Total n/ \% \\
\hline GAP & $17 / 44.73$ & $21 / 55.27$ & $38 / 100$ \\
LAP & $13 / 59.09$ & $9 / 40.91$ & $22 / 100$ \\
Total & $30 / 50.0$ & $30 / 50.0$ & $60 / 100$ \\
\hline
\end{tabular}

C: Classification

GAP: Generalized aggressive periodontitis

LAP: Localized agressive periodontitis

According to 1999 classification, the mean age of generalized chronic periodontitis patients was $47.42 \pm 10.67$, and the mean age of localized aggressive periodontitis patients was $22.75 \pm 3.40$.
The age and gender distribution of patients diagnosed according to 1999 classification is shown in Table 3. 
Table 3. The age and gender distribution of patients who diagnosed according to 1999 classification

\begin{tabular}{ccccc}
\hline \multirow{2}{*}{$\begin{array}{c}\text { 1999 C } \\
\mathrm{n} / \%\end{array}$} & $\begin{array}{c}\text { Male } \\
\mathrm{n} / \%\end{array}$ & $\begin{array}{c}\text { Female } \\
\mathrm{n} / \%\end{array}$ & $\begin{array}{c}\text { Total } \\
\mathrm{n} / \%\end{array}$ & Mean \pm sd. \\
\cline { 2 - 5 } GAP & $14 / 10.52$ & $24 / 13.18$ & $38 / 12.06$ & $36.33 \pm 6.86$ \\
GCP & $99 / 74.43$ & $135 / 74.17$ & $234 / 74.28$ & $47.42 \pm 10.67$ \\
LAP & $12 / 9.02$ & $10 / 5.49$ & $22 / 6.98$ & $22,75 \pm 3.40$ \\
LCP & $8 / 6.03$ & $13 / 7.16$ & $21 / 6.68$ & $42,00 \pm 6.08$ \\
Total & $133 / 100$ & $182 / 100$ & $315 / 100$ & $43.99 \pm 9.39$ \\
\hline
\end{tabular}

C: Classification

GAP: Generalized aggressive periodontitis

GCP: Generalized chronic periodontitis

LAP: Localized agressive periodontitis

LCP: Generalized chronic periodontitis

According to 2017 classification, the mean age of reduced periodontitis patients was $42.05 \pm 7.57$, and the mean age of SIV-GB patients was $52.0 \pm$
6.34. The age and gender distribution of patients diagnosed according to 2017 classification is shown in Table 4.

Table 4. The age and gender distribution of patients who diagnosed according to 2017 classification

\begin{tabular}{ccccc}
\hline \multirow{2}{*}{ 2017 C } & \multicolumn{3}{c}{ Gender } & Age \\
\cline { 2 - 5 } & $\begin{array}{c}\text { Male } \\
\text { n } / \%\end{array}$ & $\begin{array}{c}\text { Female } \\
\text { n } / \%\end{array}$ & $\begin{array}{c}\text { Total } \\
\text { n } / \%\end{array}$ & Mean \pm sd. \\
\hline RPG & $4 / 3.01$ & $7 / 3.84$ & $11 / 3.49$ & $53.00 \pm 8.49$ \\
N-RPG & $1 / 0.75$ & $1 / 0.54$ & $2 / 0.63$ & $52.19 \pm 5.32$ \\
RP & $20 / 15.03$ & $27 / 14.83$ & $47 / 14.92$ & $42.05 \pm 7.57$ \\
SII-GB & $11 / 8.27$ & $8 / 4.39$ & $19 / 6.03$ & $51.00 \pm 14.00$ \\
SII-GC & $10 / 7.51$ & $12 / 6.59$ & $22 / 6.98$ & $53.50 \pm 5.97$ \\
SIII-GA & $2 / 1.50$ & $4 / 2.19$ & $6 / 1.90$ & $37.00 \pm 4.69$ \\
SIII-GB & $16 / 12.03$ & $23 / 12.63$ & $39 / 12.38$ & $46.17 \pm 9.58$ \\
SIII-GC & $46 / 34.62$ & $53 / 29.12$ & $99 / 31.42$ & $40.13 \pm 10.60$ \\
SIV-GB & $2 / 1.50$ & $5 / 2.74$ & $63 / 2.22$ & $52.00 \pm 6.34$ \\
SIV-GC & $21 / 15.78$ & $42 / 23.13$ & $315 / 100$ & $42.70 \pm 18.02$ \\
Total & $133 / 100$ & $182 / 100$ & & $43.99 \pm 9.39$ \\
\hline
\end{tabular}

C: Classification

RPG: Reduced periodontium with gingival inflammation

N-RPG: Non periodontitis caused reduced periodontium with gingival inflammation

RP: Reduced periodontium

According to 1999 classification, $55.0 \%$ of smokers were diagnosed as generalized chronic periodontitis, and $35.41 \%$ of diabetics were diagnosed as localized chronic periodontitis. Distribution of smokers and diabetic patients is shown in Table 5.

Table 5. Distribution of smoker and diabetic patients who diagnosed according to 1999 classification

\begin{tabular}{ccc}
\hline 1999 C & Smoker patients $\mathrm{n} / \%$ & Diabetic patients $\mathrm{n} / \%$ \\
\hline GCP & $33 / 55.0$ & $31 / 64.59$ \\
LCP & - & $17 / 35.41$ \\
GAP & $19 / 31.66$ & - \\
LAP & $8 / 13.34$ & - \\
Total & $60 / 100$ & $48 / 100$ \\
\hline
\end{tabular}

\footnotetext{
C: Classification
}

GAP: Generalized aggressive periodontitis

GCP: Generalized chronic periodontitis

LAP: Localized agressive periodontitis

LCP: Generalized chronic periodontitis 
According to 2017 classification, $31.66 \%$ of smokers were diagnosed as SIII-GC and $37.5 \%$ of diabetics were diagnosed as SII-GC. Distribution of smokers and diabetic patients is shown in Table 6.

Table 6. Distribution of smoker and diabetic patients who diagnosed according to 2017 classification

\begin{tabular}{ccc}
\hline 2017 C & Smoker $\mathrm{n} / \%$ & Diabetic $\mathrm{n} / \%$ \\
\hline SII-GC & $5 / 8.34$ & $18 / 37.5$ \\
SII-GB & $6 / 10.0$ & - \\
SIII-GB & $11 / 18.34$ & $7 / 14.58$ \\
SIII-GC & $19 / 31.66$ & $9 / 18.75$ \\
SIV-GB & - & - \\
SIV-GC & $12 / 20.0$ & $9 / 18.75$ \\
RP & $7 / 11.66$ & $5 / 10.41$ \\
Total & $60 / 100$ & $48 / 100$ \\
\hline
\end{tabular}

C: Classification

RP: Reduced periodontium

\section{DISCUSSION}

The 2017 classification system was developed in order to accommodate advances in knowledge derived from both biological and clinical research. The new classification characterizes periodontitis using a staging and grading system. ${ }^{11}$ Periodontal health, gingival health, and gingival diseases on an intact and reduced periodontium are clearly defined for the first time. ${ }^{12}$

Of patients diagnosed with generalized chronic periodontitis or with localized chronic periodontitis according to 1999 classification, $17.94 \%$ and $23.80 \%$, respectively, were rediagnosed as having periodontitis-caused reduced periodontium with clinical gingival health under the 2017 classification system. Determining the current disease status of a patient who received periodontal therapy in the past is important in the new classification system. ${ }^{13}$ A successfully-treated periodontitis patient may appear to be healthy, but a periodontitis patient remains a periodontitis patient for life. Clinical gingival health may be found in a patient with a history of periodontitis who was successfully treated and is currently stable. ${ }^{14}$ Although patients are clinically healthy, periodontal stability requires careful maintenance and continued risk-factor control, because the disease may progress at any time. ${ }^{12,15}$

Of the patients diagnosed with generalized chronic periodontitis according to 1999 classification, $4.7 \%$ were re-diagnosed as having reduced periodontium with gingival inflammation. Dental plaque-induced gingivitis may arise on a reduced periodontium in a currently stable periodontitis patient in whom clinical inflammation has been eliminated. Therefore, patients should be closely monitored during periodontal maintenance for any reactivation of periodontitis. $^{4,16}$

Of the patients diagnosed with localized chronic periodontitis according to 1999 classification, $9.53 \%$ were re-diagnosed as having reduced periodontium with gingival inflammation from non-periodontitis causes, due to attachment loss caused by orthodontic treatment. Alveolar bone loss or attachment loss due to causes other than periodontitis was classified as reduced periodontium in a non-periodontitis patient, according to the new classification. ${ }^{17}$

Chronic periodontitis patients were classified into different stages according to the new classification system. Patients can be diagnosed in a more detailed and precise way in the new classification, because the old classification is based solely on severity, while staging is now taken into account using complexity factors that affect treatment success, in addition to the standard dimensions of severity and extent. ${ }^{3}$ Although chronic periodontitis patients were diagnosed as to different stages, there were no patients diagnosed as SI. This may be due to the absence of SI patients in this sample group, or because patients who would have been designated as SI were not diagnosed as having periodontitis in the 1999 classifications, because the worstaffected teeth guided the 2017 classifications, whereas diagnosis of periodontitis was based on 
the mean CAL of the entire dentition in the 1999 classification. ${ }^{3,13}$

Chronic periodontitis patients were classified into different grades; $2.35 \%$ of chronic periodontitis patients were diagnosed as Grade A, which assumes a slow rate of progression, while $48.65 \%$ were diagnosed as Grade C, which indicates a high rate of disease progression. This means that almost half of chronic periodontitis patients are at risk for further progression of the disease and possibly poor outcomes of treatment. The reason for the high number of Grade $\mathrm{C}$ patients, despite slow to moderate rates of disease progression in patients with chronic periodontitis, can be explained as follows: if the patient has risk factors associated with greater disease progression or is less responsive to bacterial reduction therapies, the grade score was raised. The high rate of patients with chronic periodontitis being diagnosed as Grade $\mathrm{C}$ affects the intensity of therapy, secondary prevention after therapy, and careful maintenance therapy. ${ }^{18,19}$

Although chronic periodontitis patients were classified into different grade levels, all patients with aggressive periodontitis were diagnosed as Grade $\mathrm{C}$, which is a predictor of adverse future disease progression in the absence of intervention for risk-factor control and treatment. While the severity of disease varies from slight to severe in individuals with chronic periodontitis, all individuals with aggressive periodontitis exhibit severe CAL. ${ }^{20}$ According to the new classification, individuals with aggressive periodontitis will experience more rapid and severe destruction than individuals with chronic periodontitis. This is also consistent with the definition of the clinical features of aggressive periodontitis in the 1999 classification. ${ }^{3,21}$

Recognized risk factors for severe destruction at an earlier age and that negatively affect treatment response have not been included in previous periodontitis classification systems, but have been used to classify a patient who is a smoker or a patient with diabetes mellitus. ${ }^{22,23}$ Improved knowledge of how risk factors affect periodontitis indicate that risk factors should be considered in the classification of periodontitis. ${ }^{24,25}$
Since including risk factors in the classification system predicts future disease susceptibility, the new classification can be seen as a future-oriented system.

According to 1999 classification, the mean age of generalized chronic periodontitis was highest, and the mean age of localized aggressive periodontitis was the lowest. This result is consisted with the literature that reports chronic periodontitis as being most prevalent in adults, while aggressive periodontitis usually affects people under 30 years of age. ${ }^{20,26}$ According to the new classification, systemic conditions, risk factors, and treatment requirements modified the stage and grade of periodontitis rather than age. Thus, making an age-dependent generalization would be inaccurate with the new classification.

In the 1999 classification, the patient who requires initial periodontal treatment and the patient who requires advanced periodontal treatment were diagnosed with periodontitis and this situation was changed with 2017 classification. In the 2017 classification, the stage of the periodontitis increases as the patient's need for periodontal treatment increases. Another difference was that in 1999 classification all individuals with periodontitis were under the same maintenance treatment protocol. In 2017 classification, the necessity of more careful maintenance treatment was demonstrated for individuals with high disease progression rate as well as grade of periodontitis.

Although our study aims to compare the previous and the new classification systems, there are certain limitations. Firstly, individuals were classified as healthy or diseased considering their clinical status, and only $\mathrm{HbA} 1 \mathrm{c}$ levels were requested from diabetic individuals. Secondly, different results may be obtained in other selected sample groups due to the nature of periodontitis.

In sum, the new classification is based on not only disease severity but also includes dimensions of an individual's disease, including complexity and risk factors. Thus, factors that influence approaches to therapy and disease outcomes are included in the classification. 


\section{ACKNOWLEDGMENT}

The study did not receive financial support.

\section{CONFLICT OF INTEREST STATEMENT}

The authors report no conflicts of interest related to this study.

\section{Periodontitis Teşhisi Konulan Bireylerin 1999 Ve 2017 Sınıflamalarına Göre Karşılaştırılması}

\section{$\ddot{O} Z$}

Amaç: Periodontitisin patofizyolojisi hakkında toplanan yeni bilgiler, önceki sinıflandırmaların tüm hastaların tanılarını koymada yetersiz kaldı̆̆ için, periodontitisin sinıflandırma sistemleri son 30 yılda birkaç kez değişti. 1999 sınıflandırma sistemi klinik uygulamada ve bilimsel çalışmalarda yaygın olarak kullanılmasına răgmen, 2017'deki yeniden sinıflandırmaya yol açan önemli sinırlamalara sahipti. Bu bağlamda, bu çalışmanın amacl, 1999 sistemi altında periodontitis tanisl konan bireylerin 2017 sistemine göre nasıl sinıflandırıldı̆̆ını değerlendirmektir. Gereç ve Yöntemler: 1999 sinıflamasına göre periodontitis tanısı alan ve son altı ayda periodontal tedavi görmeyen katılımcılar çalışmaya dahil edildi. Hasta değerlendirme prosedürü, periodontal indekslerin alınmasl ve tam ăgız radyografisi ile kapsamlı bir periodontal tanıdan oluşmaktaydl. Bulgular: Çalışmaya toplam 315 birey (133 erkek ve 182 kadın) dahil edildi. Yeni sinuflandırmaya göre, daha önce 1999 sinıflandırmasına göre generalize kronik periodontitis tanisı konan 42 hasta (\%17,94), azalmış periodonsiyum ile sağllkll, 11 (\%4,7) hasta ise azalmış periodonsiyum ile dişeti iltihabı olarak sınıflandırıldı. $63(\% 26,92)$ hasta SIII-GC ve 33 hasta $(\% 14,14)$ SVGC olarak sınıflandırıldı. Sonuçlar: Yeni sınıflandırma sistemi sadece hastalık şiddetini değil, aynı zamanda bireye özgü komplekslik ve risk faktörlerini de içermektedir. Anahtar Kelimeler: Sinıflandırma, tanı, hastallk, periodontitis.

\section{REFERENCES}

1. Özdemir H, Develioğlu H, Yamalık N, Aydın H, Eren K. Comparative analysis of the potential effect of phase I therapy on gingival crevicular fluid myeloperoxidase levels in non-diabetic and diabetic patients with periodontitis. Cumhuriyet Dent J 2014; 17:256-266.
2. Suzuki J. Diagnosis and classification of the periodontal diseases. Dent Clin N Am 1988;32:195216.

3. Flemmig TF. Periodontitis. Ann Periodontol 1999; 4:32-37.

4. G Caton J, Armitage G, Berglundh T, Chapple IL, Jepsen S, Kornman KS, et al. A new classification scheme for periodontal and peri-implant diseases and conditions-Introduction and key changes from the 1999 classification. J Periodontol 2018;89:1-8

5. Tonetti MS, Greenwell H, Kornman KS. Staging and grading of periodontitis: Framework and proposal of a new classification and case definition. J Clin Periodontol 2018;45:149-161.

6. Chapple IL, Mealey BL, Van Dyke TE, Bartold PM, Dommisch H, Eickholz P et al. Periodontal health and gingival diseases and conditions on an intact and a reduced periodontium: Consensus report of workgroup 1 of the 2017 World Workshop on the Classification of Periodontal and Peri-Implant Diseases and Conditions. J Periodontol 2018;89:74-84.

7. Lindhe J, Ranney R, Lamster I, Charles A, Chung $\mathrm{CP}$, Flemming $\mathrm{T}$, et al. Consensus report: chronic periodontitis. Ann Periodontol 1999;4:38.

8. Lang N, Bartold PM, Cullinan M, Jeffcoat M, Mombelli A, Murakami S, et al. Consensus report: aggressive periodontitis. Ann Periodontol 1999;4:53.

9. Dietrich T, Ower P, Tank M, West NX, Walter C, Needleman I, et al. Periodontal diagnosis in the context of the 2017 classification system of periodontal diseases and conditions-implementation in clinical practice. Br Dent J 2019;226:16-22.

10. Papapanou PN, Sanz M, Buduneli N, Dietrich T, Feres M, Fine DH, et al. Periodontitis: Consensus report of workgroup 2 of the 2017 World Workshop on the Classification of Periodontal and Peri-Implant Diseases and Conditions. J Periodontol 2018;89:173182.

11. Tonetti MS, Sanz M. Implementation of the new classification of periodontal diseases: Decision-making algorithms for clinical practice and education. J Clin Periodontol 2019;46:398-405.

12. Lang NP, Bartold PM. Periodontal health. J Clin Periodontol 2018;45:9-16.

13. Caton JG, Armitage G, Berglundh T, Chapple IL, Jepsen S, Kornman KS, et al. A new classification scheme for periodontal and peri-implant diseases and 
conditions-Introduction and key changes from the 1999 classification. J Periodontol 2018;89:1-8.

14. Kumar A. Periodontal health: A welcome addition. J Indian Soc Periodontol 2019;23:297-298.

15. Walter C, Chapple IL, Ower P, Tank M, West NX, Needleman I, et al. Periodontal diagnosis in the context of the BSP implementation plan for the 2017 classification system of periodontal diseases and conditions: presentation of a patient with severe periodontitis following successful periodontal therapy and supportive periodontal treatment. $\mathrm{Br}$ Dent $\mathrm{J}$ 2019;226:411-413.

16. Murakami S, Mealey BL, Mariotti A, Chapple IL. Dental plaque-induced gingival conditions. J Clin Periodontol 2018;45:17-27.

17. Bhatia A, Bains SK and Mehta R. A New Classification Scheme for Periodontal diseases and Conditions: A Review. J Adv Med Dent Sci Res 2018; 6:95-98.

18. Dorri M. Periodontal diseases: New classification for periodontal diseases. Br Dent J 2018;225:686.

19. Delatola C, Loos B, Laine $M$. Classification of periodontal diseases: history, present and future. Analecta Periodontol 2017;26:13-29.
20. Stabholz A, Soskolne WA, Shapira L. Genetic and environmental risk factors for chronic periodontitis and aggressive periodontitis. Periodontol 2000 2010;53:138-153.

21. Fine DH, Patil AG, Loos BG. Classification and diagnosis of aggressive periodontitis. J Clin Periodontol 2018;45:95-111.

22. Genco RJ, Borgnakke WS. Risk factors for periodontal disease. Periodontol 2000 2013;62:59-94.

23. Wiebe CB, Putnins EE. The periodontal disease classification system of the American Academy of Periodontology-an update. J Can Dent Assoc 2000;66:594-599.

24. Bouchard P, Carra MC, Boillot A, Mora F, Rangé H. Risk factors in periodontology: a conceptual framework. J Clin Periodontol 2017;44:125-131.

25. Sarı A, Şenyurt SZ, Üstün K, Kul S, Erciyas K. Evaluation of the Effects of Periodontal Disease Severity on Social Anxiety Level. Cumhuriyet Dent J 2019;22:92-101.

26. Oshman S, El Chaar E, Lee YN, Engebretson S. Effect of patient age awareness on diagnostic agreement of chronic or aggressive periodontitis between clinicians; a pilot study. BMC Oral Health 2017;17: 27. 